\title{
The Effect of Climate Change on Agricultural Production among Farmers in Kwali Area Council of Federal Capital Territory of Nigeria
}

\author{
F.U. Ebele (Ph.D) \\ Department of Science \& Environmental Education \\ University of Abuja, Abuja Nigeria \\ B.G. Aregbesola \\ Department of Science \& Environmental Education \\ University of Abuja, Abuja Nigeria \\ D.T. Haastrup \\ Department of Science \& Environmental Education \\ University of Abuja, Abuja Nigeria \\ E. Adams \\ Department of Science \& Environmental Education \\ University of Abuja, Abuja Nigeria
}

\begin{abstract}
This study examined the effects of climate change on agricultural production among farmers in Kwali Area Council of the Federal Capital Territory, Abuja Nigeria. A total of 150 farmers from every community in the Area Council were randomly selected. The main instrument used in this research work was questionnaire which consist of twentyone different questions to identified the issues on climate change in the area council including the intervention they have enjoyed so far from the government. The instrument was validated by having one climate expert, one lecturer from Department of Science \& Environmental Education University of Abuja and one lecturer from Department of Agriculture Science Federal University of Technology Minna State (FUT). Data collated for the study were analyzed using frequency counts and mean statistics. Results of the descriptive analysis demonstrate that rise in temperature, solar radiation, low rainfall and the presence of excessive of nitrogen as a result of climate change are affecting agricultural production in Kwali Area Council. Thus, there is need for immediate intervention to save future production of food from this area council, also to help provide jobs for their youth since farming is their major occupation and to protect their farmlands from losing vital nutrients which can support agricultural production.
\end{abstract}

Keywords: Kwali, Climate Change, Agricultural Production, Farmers.

\section{INTRODUCTION}

Despite technological advances, such as improved varieties, genetically modified organisms and irrigation systems, weather is still a key factor in agricultural productivity as well as soil properties and natural communities. The effect of climate on agriculture is related to variability in local climates rather than in global climate patterns. The earth's average surface temperature has increased by $1^{0} \mathrm{~F}$ in just over the last century Agronomist, (2007). Consequently, agronomists consider that any assessment has to be individually considered for by each local area. Despite this, agriculture trade has grown in recent years and now provide 
significant amount of food on a national level to major importing countries also to exporting ones. Agriculture which is one of the basic producers of the necessity of life sustainer cries for attention. Thus, both the local and the international aspect of trade and security in term of food imply the need to consider the effect of climate change on every scale.

The need to look into this saga has caused different scholar to work on the variation/relationship between climate and agriculture. Anyanwu, (2009) said that the effects of climate change and agriculture there various factors that tampered with agriculture products via the climate. Such as: temperature; precipitation; wind; relative humidity; rain fall; and so on. Kassam \& Kowal, (2002) observed that in West Africa crop production which is the basic agricultural activity is affected by climate of the location and the genetic make-up of the plant. Ayoade, (2002) studied climate and agriculture in the tropics and stated that any agriculture system is man-made ecosystem that depends on the climate to function just like the natural ecosystem. Throughout history, agricultural enterprises have coped with changes in climate through changes in management and in crop.

\section{Significance of the Study}

It is hoped that the result of this paper will enable government at all levels to step-in to the difficulty Nigerians farmers are facing due to climate change tricky. In order to boost agricultural output of the country and make food available for the masses and it will also cut down the rate of importation of foods. It will also help farmers from other parts of the country and outside the country to venture into the use of nurture land in Nigeria for agricultural purpose, creation of employment for the youth and rise in the economy. NGOs, philanthropists, private individuals and agriculturists should help in educating the farmers' on climate change impact on agricultural products. Finally, the paper will call the attention of concern bodies on climate change to rise to the needs of famers' in Kwali Area Council and Nigeria at large.

\section{Background Literature}

Nigeria is located in the western part of Africa between latitudes $4^{\circ} 16^{\prime} \mathrm{N}$ and $13^{\circ} 52^{\prime} \mathrm{N}$; and between longitudes $2^{\circ} 49^{\prime} \mathrm{E}$ and $14^{\circ} 37^{\prime} \mathrm{E}$. It occupies a total land area of $923,768 \mathrm{~km} 2 \mathrm{with}$ a population of 140 million people (2006 census). Nigeria operates a federal system with 36 States and the Federal Capital Territory. There are 774 local governments at the third tier level, which support the Federal system. The country has over 250 ethnic groups with rich cultural endowment. Nigeria is one of the largest countries in Africa, with a total geographical area of 923768 square kilometers and an estimated population of 155,215,573 million. It lies wholly within the tropics along the Gulf of Guinea on the western coast of Africa. Nigeria has a highly diversified agro-ecological condition, which makes possible the production of a wide range of agricultural products George, (2012). The Federal Capital Territory (FCT-Abuja: $8^{\circ} 49123 l l \mathrm{~N}$; $7^{\circ} 04110 l l \mathrm{E}$ ) of Nigeria is one of the fastest growing urban settlements in the world (Encyclopaedia of Nations, 2012) that needs adequate food to feed the rapidly growing population. With an ever decreasing land available for farming due to urbanization of Abuja Chuwang, Oyerinde and Emmanuel (2012), there is need to increase, or at least maintain the production of crops per unit land area on the remaining over-cropped lands (characterized by diminishing soil fertility) so as to meet the increased demand for food given the rapid population increase.

Weather conditions in Abuja are influenced by its location within the Niger-Benue trough on the windward side of the Jos Plateau and at the climate transition zone between the essentially 'humid' south and the 'sub-humid' north of the country. The climatic dictates of the FCT are essentially from the south West to the North West due to the rising elevation from the Gurara 
valley in the south west, to the Bwari-Aso hills and the Agwa -Karu hills to the north east. The high temperatures and the relative humidity in the Niger-Benue trough give the Federal Capital Territory a heating effect but the increasing elevation towards the north east reduces the heat in areas like on the Gwagwa plains where the Federal Capital City (FCC) is sited than on the Iku-Gurara plains to the west. The FCT is divided into six area councils namely, Abuja Municipal, Gwagwalada, Abaji, Kuje, Bwari and Kwali (www.abhinavjournal.com, retrieved 4/2/2014). Kwali is a Local Government Area of the Federal Capital Territory (Nigeria). Its headquarters are in the town of Kwali. It has an area of $1,206 \mathrm{~km}^{2}$ and a population of 85,837 at the 2006 census (Wikipedia, retrieved 2014).

Agriculture is considered a critical sector in the world economy. It contributes $24 \%$ of global Gross Domestic Product and provides employment to 1.3 billion people or $22 \%$ of the world's population. In many of the developing countries, increasing agricultural production has been one of the most important priorities for agricultural development programs Hosseini, Mohammadi and Mirdamadi, (2011). United Nations Report (2010) states that agriculture has shown to produce significant effects on climate change, primarily through the production and release of greenhouse gases such as carbon dioxide, methane and nitrous oxide, but also by altering the earth's land cover, which can change its ability to absorb or reflect heat and light, thus contributing to radioactive forces. Agricultural production is the backbone of food production in Nigeria since we exclusively depend on perishable foods/annual products unlike the developed countries where canned/processed and other forms preserved foods flux their market. In Nigeria, agriculture is the main source of food and employer of labour employing about 60-70 per cent of the population Manyong, Ikpi, Olayemi, Yusuf, Omonoma Okoruwa, Idachaba, (2005). All living organism both plant and animal depend on food which is product of several crops. And crops on the other hand depend on the climate change for effective output; in Nigeria today most of our crops are not at their maximum production which can be traced to either slight or drastic change in temperate, rainfall, moisture etc.

The speculation of world population is expected to growth double its size before the year 2050, and the larger part of this population rest in developing countries which therefore necessitate increase in proportional crop growth to meet up this escalate population. Nigeria faces huge food security challenges. About 70 percent of the populations live on less than N 100 (US\$ 0.70) per day, suffering hunger and poverty. Akinsanmi, (2005) explained that despite the reputation of petroleum resource-dependent in Nigeria as an agrarian economy. Presently this sector provides over $40 \%$ of gross domestic product (GDP) with 60 and $70 \%$ of the population productively engaged in farming. But large regional differences exist. For instance, in the southeast, $22 \%$ of the people live in rural areas with most of them engaged in non-farming activities. Nigeria has about 79 million hectares of arable land, of which 32 million hectares are cultivated. Over $90 \%$ of agricultural production is rain-fed. Smallholders, mostly subsistence producers account for $80 \%$ of all farm holdings. Both crop and livestock production remains below potentials. Inadequate access to and low uptake of high quality seeds, low fertilizer use and inefficient production systems lead to this shortfall. Despite a seven percent growth rate in agricultural production (2006-2008), Nigeria's food import bill has risen. The growing population is dependent on imported food staples, including rice, wheat and fish. 


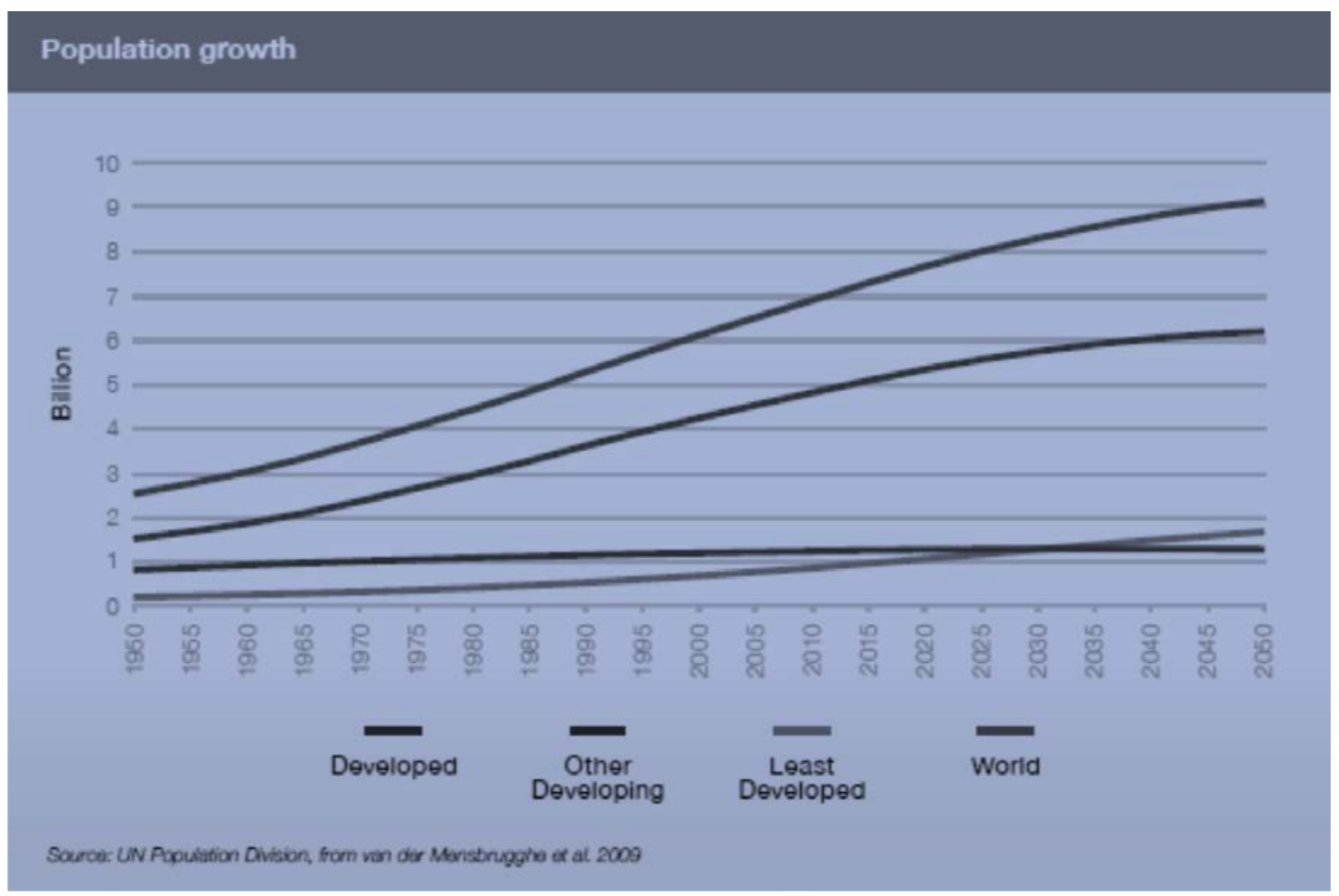

Figure 1: Population Growth of Nigeria

\section{Climate Change \& Agricultural Production: A Retrospective}

Crop responses to a changing climate reflect the interplay among three factors: rising temperatures, changing water resources and increase in carbon dioxide concentrations. The duration and pattern of rainfall also determine the growing seasons which ranges from 12 months in a year through single and double rainfall maxima to virtually rainless condition Kowal \& Kassam, (1999). Similarly, crops require certain amount of rainfall and these amounts should be distributed in such a way that the supply is adequate throughout the growing seasons of crop for successful growth, development and yield Osu, (2004). Also, Mitchell, Johns, Ingram, \& Lowe, (2004) analyzed the mean annual rainfall for Kwali Area Council ranges from $1,500 \mathrm{~mm}-2,000 \mathrm{~mm}$. The mean annual rainfall duration is seven (7) months, from AprilOctober, the rain starts in April increase gradually to September with the mean annual value of about $286 \mathrm{~mm}$ and decrease to $6 \mathrm{~mm}$ in December.

Most of the crop in the tropics requires high temperature all year round. Low temperature kills or damage crops and prolongs breeding of plants; note temperatures above freezing retards plant growth and kills those crops adapted only to warm conditions Ayoade, (2004). Too high temperature is not as destructive to crops as too low temperature as far as, the moisture supply to the crop is sufficient enough to prevent wilting and the crop is adapted to the climate region. However, excessive heat destroys the plant and it has a dehydrating effect on plants. Also rapid rate of transpiration may lead to wilting. Extreme high temperature affects the time of crop ripening as well as growth rate and the reproductive capacities of crops tend to decrease under high temperature condition Ayoade, (2005). The relative humidity which is evidence of dew and precipitation fogs with high temperature has the tendency to increase the moisture on leaves surface and increase favorable site for pathogen Hayward \& Oguntoyinbo, (1987).

Leonard, (2003) explained that the relative humidity in Kwali Area Council has a monthly value of over $50 \%$ and $75 \%$ during the raining season from April-October and decreases to 
$52 \%$ at the onset of the dry season. Kassam, \& Hodgkin, (2009) accounts that the wind speed in Kwali ranges from a mean monthly total of $7.1 \mathrm{~m}$ which increases from $7.8 \mathrm{~m}$ in August and decreases to about $5.8 \mathrm{~m}$ in December. Climate change effects on agricultural production differ across the world and how to determining it effects on agricultural products is complex in which varieties of effects are likely to occur. Changes in temperature, rainfall pattern and the increase in $\mathrm{CO}_{2}$ level projected to accompany climate change. According to Parrya, Rosenzweigb, Iglesiasc, Livermored, Fischere, (2004) the possible negative effects of climate influence on agricultural production can be due to the following:

o Geographical shift and yield changes in agriculture

o Reduction in the quality of $\mathrm{H} 2 \mathrm{O}$ available for irrigation

o Loss of land through sea level rise and associated salinization.

Agricultural facilities contribute approximately 20\% of the annual increase in anthropogenic greenhouse gas emission. This sector contributes to global warning through carbon-dioxide $\mathrm{CO}_{2}$; methane $\mathrm{CH}_{4}$ and Nitrogen $\mathrm{N}_{2} \mathrm{O}$ gas emission. Primary deforestation due to agricultural expansion and land speculation is one of the major causes of carbon emissions when natural vegetation is converted into agricultural land and a large portion of soil carbon can be lost as plants and dead organic matter are removed. $\mathrm{CO}_{2}$ can also be lost during burning of agricultural crop waste; $\mathrm{NH}_{4}$ is also one of greenhouse gases which can be released from paddy field (91\%) and burning of agricultural waste (9\%) consequently methane has a direct effect on agriculture production by resulting in less troposphere ozone, this is a pollutant which is harmful to both human health and plant Oguntoyinbo, (1987). Also the effect of climate on pests may add to the effect of other factors such as the overuse of pesticides and the loss of biodiversity, which already contribute to plant pest and disease outbreaks Hollaway, Arnold, Challinor, Emberson, (2011).

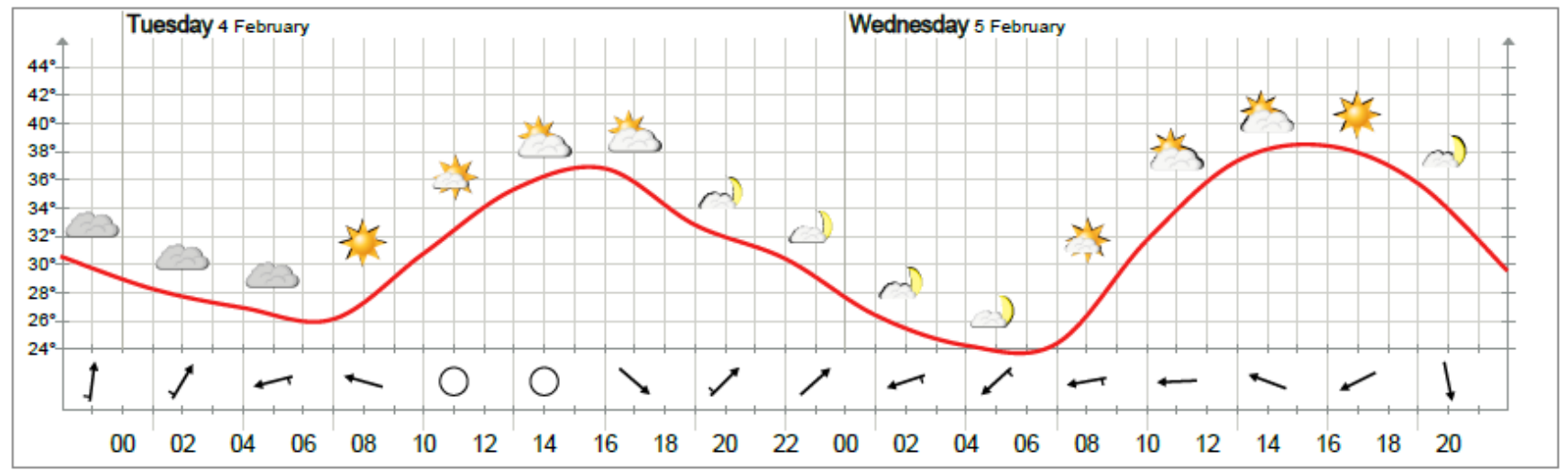

Source: www.yr.no/place/Nigeria/Abuja/Kwali/retrieved 3/2/2014

Figure 2: Meteogram for Kwali Area Council

It could be synthesized that from all climate change study highlighted, its major outcome is the identification of effect of climate change on agricultural production among farmers. In Kwali, a needs analysis study was initiated in an effort to establish empirical evidence of the farmers' needs in meeting the climate change on agricultural production. In 2005, U.S Environmental Protection Agency Magazine published that changes in the frequency of extreme climate changes in rainfall and temperature could be damaging and costly to agriculture. Some factors affect the response of plants include the availability of plant nutrients, crop species, temperature precipitation and other environmental factors. These studies therefore served as a point of focal-point for this paper, which specifically focuses on effects of climate change on agricultural production among framers in Kwali Area Council of the Federal Capital Territory of Nigeria. 


\section{Aims of the Study}

The main aim of this study is to identify the most effects of climate change on agricultural production in Kwali Area Council. This is essential so as relative measures can be undertaken to

Prepare farmers in meeting with these local challenges as well as confronting issues of globalization. This study also seeks to identify the following objectives:

o To assess the effect of climate change on agricultural production in Kwali Area Council

0 To assess the extent to which heavy rainfall affects agriculture production in Kwali Area Council

o To ascertain the extent to which high temperature affects crop production in Kwali Area Council

o To assess the extent to which solar radiation affects agricultural productivity in Kwali Area Council

\section{Research Question}

The following research questions guided this study:

o To what extent does temperature rise affect agricultural production in Kwali Area Council?

o To what extent does solar radiation affect crop production in Kwali Area Council?

o To what extent does heavy rainfall affect agricultural production in Kwali Area Council?

o What is the extent to which nitrogen excessiveness affects crop yield in Kwali Area Council?

\section{Research Design}

\section{RESEARCH METHODOLOGY}

The research design employed in this study is survey, using questionnaire as the prime instrument. The survey design is chosen so that generalizations can be made from the samples representing the population (Creswell, 2005; Kerlinger and Lee, 2002). Neuman (2000) argues that such an approach can be justified in terms of the nature of information gathered. This study garnered information on the Kwali farmers based on effects of climate change on agricultural production. The nature of such data justifies the suitability of the survey design employed.

\section{The Samples}

The population of this study comprised practicing farmers in Kwali Area Council. Using the research questions developed as points of reference, a stratified random sampling of respondents was made, taking these factors into consideration; gender of the respondents (male vs. female), geographical location of the farms involved (rural vs. urban) and the respondents' area of specialization (cooperative, commercial, plantation and peasant). As a result, the total population of Kwali Area Council according to census, (2006) 87,837 constituted the population of the study. Kwali is bonded with a total land area of $1,206 \mathrm{~km}^{2}$. Their major means of survival as well as occupation is farming (agriculture). 150 farmers were randomly selected as respondents for this survey from the total population. Table 1 summarizes the demographic data of the farmers who participated in this study. 


\begin{tabular}{|c|c|c|c|c|c|}
\hline \multirow{2}{*}{\multicolumn{2}{|c|}{ Farm Location }} & \multicolumn{4}{|c|}{ Area of Specialization } \\
\hline & & Cooperative & Commercial & Plantation & Peasant \\
\hline \multirow[t]{2}{*}{ Urban } & Male & 15 & 15 & 5 & 10 \\
\hline & Female & 5 & 7 & 3 & 5 \\
\hline \multirow[t]{2}{*}{ Rural } & Male & 3 & 13 & 2 & 40 \\
\hline & Female & 2 & 7 & 1 & 17 \\
\hline
\end{tabular}

Source: Field Work, 2011

As displayed succinctly in Table 1 , almost $52.0 \%$ of the farmers in the urban areas are largescale majors compared to only $18.7 \%$ in the rural areas. For both locations, most of the farmers are majoring in commercial in the urban $(22 ; 14.7 \%)$ area and peasant farming in the rural area $(57 ; 38.0 \%)$ and the least number of farmers are majoring in cooperative (urban, $n=20$; rural, $\mathrm{n}=5$ ).

Nonetheless, there are about a few percentages of farmers majoring in plantation both in the rural and urban areas (urban, $n=8$; rural, $n=3$ ). The percentages of farmers who are majoring in peasant farming in urban and rural areas are $10.0 \%$ and $38.0 \%$ respectively. Analysis across gender shows that $12.0 \%$ the male respondents are cooperative farmers while $4.7 \%$ are female; $18.7 \%$ of the farmers that are majoring in commercial farming are male while $9.3 \%$ of them are female. $4.7 \%$ of the plantation farmers are male while $2.7 \%$ are female; $33.3 \%$ of the farmers major in peasants farming and $14.7 \%$ of them are female. When the distribution of large-scale farmers is examined across farm location, it was found that the ratio of male to female farmers in both rural and urban schools is about 2.1 to 1 . From the ratio, it could be inferred that for both urban and rural areas, there are more male compared to female farmers. It was also found that only $10.0 \%$ of farmers in the urban schools are not peasant farmers. In contrast, the percentage is slightly higher in rural areas with almost $38.0 \%$ of farmers are peasant farmers.

\section{The Instrument}

The analysis instrument used in this study is developed by using the Effects of Climate Change on Agricultural Production (ECCAP) developed by researcher. Items were carefully and collectively crafted, which reflect the current the effect of climate change on agricultural production in Kwali Area Council. The overall process of item development involved five main stages. Firstly, the existing climate changes were consecutively reviewed. Secondly, a thorough review and analysis of the climate change and agricultural production literature were conducted. Thirdly, in order to identify the effects of climate change on the agricultural products structured interviews were conducted which involved some experienced farmers within the council. The interview data were used as background information in constructing the needs items. Fourthly, a panel of experts in the area of climate change and agricultural production were engaged to add, edit, or eliminate irrelevant items from the initial pool of items.

At the final stage of items construction, the instrument was validated by having one climate expert, one lecturer from Department of Science \& Environmental Education University of 
Abuja and one lecturer from Department of Agriculture. They reviewed the items with respect to its readability, clarity and ease of response. Instructions or items that were equivocally stated were identified and improvements were made. Data for the study were collected using questionnaire. Section A consists of farmers' bio data and section B consists of effects of climate change on agricultural production among farmers' was designed and constructed to determine the extent to which a farmer agree or disagree with some 21questions on climate change \& agricultural production. The questionnaire was administered to the farmers in their homes, farmers and offices while they returned the questionnaire to the researcher and the assistant immediately they answer them. Data analysis involved computing for each item with frequency counts and mean statistics of farmers' selecting Strongly Agree (SA), Agree (A), Disagree (D) or Strongly Disagree (SD).

Table 2: Responses of 150 farmers to the Climate Change on Agricultural Production in Kwali Area Council Questionnaire

S/No Question

\section{Responses}

1. Are you a farmer?

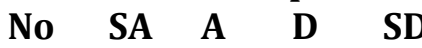

$\begin{array}{lllll}4 & 3 & 2 & 1 & X\end{array}$

2. Do you practice any particular type of
farming?

$\begin{array}{llllll}150 & 80 & 65 & 5 & - & 3.50\end{array}$

Inference

3. Do you apply any particular method of farming?

4. Do you practice mechanized farming?

150

$77 \quad 73$

3.50 Agreed

$\begin{array}{lllllll}150 & 57 & 73 & 21 & - & 3.28 & \text { Agreed }\end{array}$

5. Do you think land is fertile enough for agricultural production?

6. Have heard of climate change?

$\begin{array}{lllllll}150 & 25 & 5 & 50 & 70 & 1.90 & \text { Disagreed }\end{array}$

$\begin{array}{lllllll}150 & 75 & 51 & 14 & 10 & 4.91 & \text { Agreed }\end{array}$

7. Have you noticed any changes on your farm

$\begin{array}{lllllll}150 & 20 & 20 & 50 & 70 & 2.07 & \text { Disagreed }\end{array}$

$\begin{array}{lllllll}150 & 15 & 25 & 40 & 70 & 1.90 & \text { Disagreed }\end{array}$

produce ever since you heard of climate change?

8. Have you ever noticed decrease in soil fertility?

9. Does your annual yield result moderately since the effect of climate change on agricultural produce

10. Has there been any improvement on your farm practices?

11. Due to nitrogen excessiveness, has there been any increase in food \& crop production?

$\begin{array}{lllllll}150 & 80 & 50 & 15 & 5 & 5.05 & \text { Agreed } \\ 150 & 26 & 24 & 70 & 40 & 2.31 & \text { Disagreed } \\ 150 & 20 & 30 & 40 & 60 & 2.06 & \text { Disagreed } \\ 150 & 38 & 40 & 37 & 35 & 3.81 & \text { Agreed }\end{array}$

12. Has there been any support offered by the $\begin{array}{lllllll}150 & 70 & 60 & 10 & 10 & 4.80 & \text { Agreed }\end{array}$ government in assisting you towards a successful crop \& food production?

13. Are there times government gives subsides on any farm items such as fertilizers, improved seed and so on?

14. Has there been any farm of education $\begin{array}{llllllll}150 & 65 & 45 & 20 & 20 & 4.55 & \text { Agreed }\end{array}$ (agricultural extension personnel) on the modern method of practicing agricultural?

$\begin{array}{lllllll}150 & 80 & 45 & 15 & 10 & 4.95 & \text { Agreed }\end{array}$

$\begin{array}{lllllll}150 & 65 & 45 & 20 & 20 & 4.55 & \text { Agreed }\end{array}$

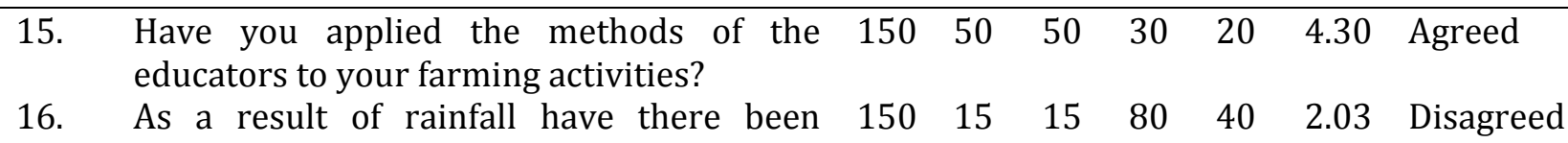


changes in the annual crop production rate?

17. Do you apply any form of manure to improve soil fertility so as to enhance good yield?

18. Do you engage in any form of irrigation in your farmland?

19. Do you think government can help mitigate $\begin{array}{lllllll}150 & 83 & 67 & - & - & 5.33 & \text { Agreed }\end{array}$ the problem of climate change?

20. Have there been individual efforts to $\begin{array}{lllllll}150 & 50 & 70 & 30 & - & 3.33 & \text { Agreed }\end{array}$ protect plant crops from experiencing climate change effects?

21. Has there been a change in rainfall pattern? $\begin{array}{llllllll}150 & 25 & 10 & 75 & 15 & 1.97 & \text { Disagreed }\end{array}$

\section{Research Question 1:}

\section{DISCUSSION OF FINDINGS}

Table 2(i): To what extent does temperature rise affect agricultural production in Kwali Area

S/No Question

\section{Council?}

Question

1. Are you a farmer? 2. Do you practice any particular type of
farming?

3. Do you apply any particular method of

4. Do you practice mechanized farming?

5. Do you think land is fertile enough for agricultural production?

6. Have heard of climate change?

7. Have you noticed any changes on your farm produce ever since you heard of climate change?

$$
\begin{aligned}
\text { - } & \sum \underline{\mathrm{fx}} \\
& =\frac{18.07}{7} \\
& =2.58
\end{aligned}
$$

$\begin{array}{ccccccl}\text { No } & \text { SA } & \mathbf{A} & \mathbf{D} & \mathbf{S D} & - & \text { Inference } \\ & \mathbf{4} & \mathbf{3} & \mathbf{2} & \mathbf{1} & \mathbf{X} & \\ 150 & 80 & 65 & 5 & - & 3.50 & \text { Agreed } \\ 150 & 77 & 73 & - & - & 3.51 & \text { Agreed } \\ & & & & & & \\ 150 & 57 & 73 & 21 & - & 3.28 & \text { Agreed } \\ & & & & & & \\ 150 & 25 & 5 & 50 & 70 & 1.90 & \text { Disagreed } \\ 150 & 75 & 51 & 14 & 10 & 4.91 & \text { Agreed } \\ & & & & & & \\ 150 & 20 & 20 & 50 & 70 & 2.07 & \text { Disagreed } \\ 150 & 15 & 25 & 40 & 70 & 1.90 & \text { Disagreed }\end{array}$

\section{Responses}

It was observed that more than $96.7 \%$ of the respondents in Kwali Area Council are professional farmers that is, most of the farmers are experienced and have farming skills. Though, majority are not operating mechanized farming due to one reason or the other. The grand mean for the research question one shows that majority of those that responded to the questionnaire are qualified farmer in the area council that is a mean of 2.58 from the mean scale of 2.5 which stands for the bench mark of accepting the question when it's above it and rejecting it when it below the bench mark. Thus, it can be concluded that the farmers in Kwali Area Council agreed that the temperature rise do affect their agricultural production. 


\section{Research Question 2:}

Table 2(ii): To what extent does solar radiation affect crop production in Kwali Area Council? S/No Question

\section{Responses}

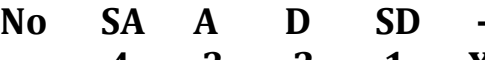

$\begin{array}{lllll}4 & 3 & 2 & 1 & X\end{array}$

1. Have you ever noticed decrease in soil

150

\section{fertility?}

2. Does your annual yield result moderately since the effect of climate change on agricultural produce?

3. Has there been any improvement on your farm practices?

4. Has there been any form of education (agricultural extension personnel) on the modern method of practicing agricultural?

5. Have you applied the methods of the educators to your farming activities?

6. Do you think government can help mitigate the problem of climate change?

7. Have there been individual efforts to protect plant crops from experiencing climate change effects? $\begin{array}{lllllll}150 & 26 & 24 & 70 & 40 & 2.31 & \text { Disagreed }\end{array}$

$\begin{array}{lllllll}150 & 20 & 30 & 40 & 60 & 2.06 & \text { Disagreed }\end{array}$

$\begin{array}{lllllll}150 & 65 & 45 & 20 & 20 & 4.55 & \text { Agreed }\end{array}$

$\begin{array}{lllllll}150 & 50 & 50 & 30 & 20 & 4.30 & \text { Agreed }\end{array}$

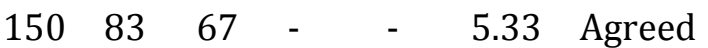

$\begin{array}{lllllll}150 & 50 & 70 & 30 & - & 3.33 & \text { Agreed }\end{array}$ $-\quad \sum \underline{\mathrm{fx}}$

Mean $X=n$

$$
\begin{aligned}
& =\frac{24.93}{7} \\
& =3.56
\end{aligned}
$$

Majority of the farmers operating at large and small scale $86.7 \%$ agreed that they have noticed decrease in soil fertility while $13.3 \%$ disagreed to the change in the soil fertility. $33.3 \%$ of the farmers agreed that annual yield result moderately since the effect of climate change on agricultural produce while mainstream of the farmers $73.3 \%$ disagreed. $33.3 \%$ of the farmers

testified to the fact that there has been improvement on their farm practices while $66.7 \%$ of them disagreed to the question. They were of the opinion that there has not been much improvement on their farm practices. $73.3 \%$ of the farmers agreed that there has been education by agricultural extension personnel on how modern agricultural practices, while the remaining $26.6 \%$ of the farmers disagreed that they ever enjoyed such training. Hand full member of the farmers $66.7 \%$ agreed to the fact that they have applied the methods of the educators to their farming activities. $100 \%$ of the farmer both elites and illiterates among them recognized the intervention of government in any problem that they have been posing treat to them and the prove to this is that $100 \%$ of the farmers agreed government can help them mitigate the problem of climate change or any other ones that may arise with time. Although, few of these farmer testified to the fact of not aware of climate change but they agreed to the fact that they do what they can to protect the farm products as $80 \%$ of them agreed that there has been individual efforts to protect plant crops from experiencing climate change effects. The grand mean 3.56, gotten from research question two showed that Kwali Area Council has been experiencing the effect of solar radiation on their crop production. 


\section{Research Question 3:}

Table 2(iii): To what extent does heavy rainfall affect agricultural production in Kwali Area Council?

S/No

Question

1. As a result of rainfall have there been changes in the annual crop production rate?

2. Do you engage in any form of irrigation in your farmland?

3. Has there been a change in rainfall pattern?

\begin{tabular}{ccccccc} 
& \multicolumn{1}{c}{ Responses } \\
No & SA & $\mathbf{A}$ & $\mathbf{D}$ & $\mathbf{S D}$ & - & Inference \\
& $\mathbf{4}$ & $\mathbf{3}$ & $\mathbf{2}$ & $\mathbf{1}$ & $\mathbf{X}$ & \\
150 & 15 & 15 & 80 & 40 & 2.03 & Disagreed \\
150 & 23 & 23 & 57 & 47 & 2.15 & Disagreed \\
150 & 25 & 10 & 75 & 15 & 1.97 & Disagreed
\end{tabular}

$$
\begin{aligned}
- & \sum \underline{\mathrm{fx}} \\
\text { Mean X } & =\mathrm{n} \\
& =\frac{6.15}{3} \\
& =2.05
\end{aligned}
$$

Results showed that there have not been changes in the annual rainfall in Kwali Area Council as $80 \%$ of the farmers disagreed that they have experienced changes in the annual crop production rate due to rainfall and $25 \%$ of the farmers agreed that they had. While $69.5 \%$ of the farmers disagreed that they have engaged in any form of irrigation on farmland $30.7 \%$ agreed that they have been using the irrigation method on their farmland. Also, the question on changing of the pattern of rainfall was another vital one as $60 \%$ of the farmers disagreed to the fact that they have enjoyed change in rainfall pattern, majority of the framers lamented that most of the time is either late rainfall or inadequate that they have been used to $23.3 \%$ of them agreed that they have noticed it. Thus, from the grand mean 2.05, from research question three it can be concluded that heavy rainfall has affect agricultural production in Kwali Area Council.

\section{Research Question 3:}

Table 2(iv): What is the extent to which nitrogen excessiveness affects crop yield in Kwali Area

\section{Council?} S/No Question
1. Due to nitrogen excessiveness, has

$\begin{array}{lllll}4 & 3 & 2 & 1 & X\end{array}$

$\begin{array}{lllllll}150 & 38 & 40 & 37 & 35 & 3.81 & \text { Agreed }\end{array}$
No SA A D SD -
there been any increase in food \& crop production?
2. Has there been any support offered by the government in assisting you towards a successful crop \& food production?
3. Are there times government gives subsides on any farm items such as fertilizers, improved seed and so on?
4. Do you apply any form of manure to improve soil fertility so as to enhance $\begin{array}{lllllll}150 & 70 & 45 & 15 & 15 & 4.60 & \text { Agreed }\end{array}$ good yield?

$\begin{array}{lllllll}150 & 70 & 60 & 10 & 10 & 4.80 & \text { Agreed }\end{array}$
$\begin{array}{lllllll}150 & 80 & 45 & 15 & 10 & 4.95 & \text { Agreed }\end{array}$

$\begin{array}{lllllll}150 & 70 & 45 & 15 & 15 & 4.60 & \text { Agreed }\end{array}$




$$
\begin{aligned}
- & \sum \underline{\mathrm{fx}} \\
\text { Mean X } & =\mathrm{n} \\
& =\frac{18.16}{4} \\
& =4.54
\end{aligned}
$$

From table 2(iv) above $52 \%$ of the farmers agreed that due to nitrogen excessiveness there has been increase in food \& crop production in Kwali Area Council although they testified that this can be attributed to other factors. While $48 \%$ of the farmers disagreed to the excessive present of nitrogen on farmlands in the area council, they are of the opinion to know more of presence of elements/compound on their farmlands and how to adequately treat them in case of any problem(s). Good numbers of the farmers $86.7 \%$ agreed that there have been supports offered by government in assisting them towards a successful crop \& food production in the area council. The benefits of government intervention is yet to get to $13.3 \%$ of the farmers as they testified that they cannot dispute the fact that they have not seen or heard about it but the fact still remains that they are yet to benefit from it. In addition, 83.3\% of the farmers agreed that there times government gives subsides on farm items such as fertilizers, improved seed and so on. They even cited example of the recent one they benefitted from which contains fertilizer, seeds (maize \& rice) and other educating programmes, also $16.7 \%$ of the farmers population disagreed to be beneficiary of this subsides farm items, this was not answered in grief as they confessed that they await the benefit of the farm items soonest. $76.7 \%$ of the farmers' population joyfully agreed that they do apply manure to improve soil fertility so as to enhance good yield that the government on her part has reached-out to them on this aspect while $23.3 \%$ disagreed to the application of manure on their farmlands; some said it does not agree with their belief while others said they do not have opportunity to get it.

From table 2(i); 2(ii); 2(iii) results showed that temperature rise, solar radiation and low rainfall have affected crop production in Kwali Area Council while table 2(iv) has given a clear picture of government intervention to agricultural production in the area council.

\section{Recommendations}

The following recommendations are provided to improve on the effect of climate change on agricultural production in Kwali Area Council:

o Government, meteorologists, geographers and established farmers should come to the aid of Kwali Area Council in terms of establishing meteorological stations in that region that allow easy access to climatology and the attention should be given to climate change in this region of Federal Capital Territory.

o Expansive extension service should be provided for farmers in Kwali Area Council so as to teach them the importance of the presence of any element (s)/compound on their farmlands.

o Also government, NGOs, philanthropists, businessmen, private organization, cooperate organization and individual should work hand-in-hand with these farmers in providing irrigation scheme in Kwali Area Council to enable the farmers to have all-round cultivation. 
o There should be more focus on research work in Kwali Area Council pertaining agricultural production.

\section{Limitation of the Study}

The following are the limitations of the study:

o There was initial reluctant acceptance by the farmer's association to use the area council for the study.

o Also language barrier delayed getting some information from the farmers' before two interpreters' set-in.

\section{Recommendations for Further Studies}

Based on the findings of the study, the following suggestions are for further research on the effect of climate change on agricultural production among farmers:

o The study can equally be carried out on any difficulty confronting the farmers' in Nigeria or any other country.

o Any other state in the country can also be chosen for a similar study comparison and possible extension of research finding.

\section{Reference}

Akinsanmi, A. (2005). Gender Relations and Food Security of Rural Families in Imo State, Southeast Nigeria. Farming and Rural Systems Economics, Vol. 68. Margraf Verlag, Weikersheim, Germany; and: Nwajiuba, C. (2012).

Doesagriculture have a future in southeast Nigeria? Inaugural lecture, No. 5. Imo State University Owerri, Nigeria

Anyanwu, (2009). Biodiversity Consideration and Sustainable Rural Development in the Agricultural Sector. Delhi, Today and Tomorrow Printers.

Ayoade, J. 0. 2004. Climate Change. Ibadan. Vantage Publishers, pp. 45-66.

Ayoade, J. (2002). Introduction to Agro Climatology. Vantage publishers, Ibadan

Ayoade, J.O. (2005). Introduction to Climatology for the Tropics. Spectrum Book Limited, Ibadan.

Chinedum, N. (Undated). Agriculture \& Food Security: Nigeria's Agriculture and Food Security Challenges.

Chuwang, P.Z., Oyerinde A.A., Emmanuel H (2012). Assessment of Cowpea Vigina Unguiculata. L. Warp) Production in the FTC, Abuja Nigeria. Unpublished Data, 2012.

George, A. (2012). Climate Change \& Agriculture: The Nigerian Story Conference Presentation FES Ghana, Accra Program Manager. Women Environmental Programme, Nigeria.

Hayward, D. and Oguntoyinbo, J.S. (1987): The Climatology of West Africa. Barnes and Neble Books, Totowa, New Jersey.

Hollaway, M.J; Arnold, S.R; Challinor, A.J; Emberson, L.D. (2011). Intercontinental Trans-Boundary Contributions to Ozone-Induced Crop Yield Losses in the Northern Hemisphere, Biogeosciences Discussions, 8, pp.86458691. DOI: $10.5194 /$ bgd-8-8645.2011.

Hosseini, S.J., Mohammadi, F., Mirdamadi, S.M. (2011). Annals of Biological Research, 2, 2, 378-387.

Kassam, A. \& Hodgkin, T. (2009). Rethinking Agriculture: Agro Biodiversity for Sustainable Production ntensification. Platform for Agro biodiversity Research (http://agrobiodiversityplatform. org/climate change/2009/05/14/ Rethinking-Agriculture Agro Biodiversity- for-Sustainable Production- Intensification/).

Kowal, J.M, and Komal, D.O. (2002). The Pattern of Water Availability and Water Requirement for Grain Sorghum Production at Samaru, Nigeria. Tropical Agriculture Trinidad. 50:21.

Kowal, J.M. \& Kassam, A.N. (1991). Agricultural Ecology of Savanna. A Study of West Africa. Oxford Univeristy Press, Oxford. U.K.

Leonard S. S; AmyL. L; David B. L \& Lee, A. Pamela A. M. (2003).Department of Geological and Environmental Sciences, Stanford University, Stanford, CA 94305, USA Center for Environmental Science and Policy Institute for International Studies, Stanford University, Encina Hall East, Fourth Floor, Stanford, CA 94305, USA. Global 
Ebele, F. U., Aregbesola, B. G., Haastrup, D. T., and Adams, E. (2014). The Effect of Climate Change on Agricultural Production Among Farmers in Kwali Area Council of Federal Capital Territory of Nigeria. Advances in Social Sciences Research Journal, 1(2), 13-26

Environmental Change 13 (2003) 255-267).A Method for Quantifying Vulnerability, Applied to the Agricultural System of the Yaqui Valley, Mexico.

Manyong, V. M., Ikpi, A., Olayemi, J. K., Yusuf, S.A., Omonoma BT, Okoruwa V, Idachaba, F.S. (2005). Agriculture in Nigeria: Identifying Opportunities for Increased Commercialization and Investment in USAID/IITA/UI Project Report Ibadan, Nigeria.

Mitchell, J. F. B., Johns, T. C., Ingram, W. J. \& Lowe, J. A. (2004). The effect of Stabilizing Atmospheric Carbon dioxide Concentrations on Global and Regional Climate Change. Geophysical Research Letters Vol. 27, pp. 29973100 .

Oguntoyinbo, J.S. (1987): Climate Variability and Food Production. West African Geographical Journal, 5(2): 139149.

Olayiwola, 0.0. (retrieved www.abhinavjournal.com 4/2/2014). Research Fellow, Department of Economics Policy Unit, Development Policy Centre (DPC), Appraisal of Urban Agriculture in Abuja, Nigeria. National Monthly Refereed Journal of Research in Commerce \& Management Abuja; Kwali Local Government Wikipedia, the free encyclopedia retrieved.

Oregon State University. (2004). Hort 233 Vegetable Crops Class Notes. http://oregonstate.edu/dept/hort/233/index.htm

Parrya, M.L; Rosenzweigb, C; Iglesiasc, A; Livermored, M; Fischere, G. (2004). Effects of Climate Change on Global Food Production Under SRES Emissions and Socio-Economic Scenarios. Global Environmental Change 14 53-67. Hadley Centre, UK Meteorological Office, Fitzroy Road, Exeter EX1 3PB, UK Goddard Institute for Space Studies, New York City, USA.

The Agronomy, (2007), Texas Tech University, Lubbock, TX. Soil Science and Agrl. Chemistry (2004), A.N.G.R. Agricultural University, India.

The Norwegian Broadcasting Corp 2014 www.yr.no/place/nigeria/abuja/kwali/retrieved 4/2/2012.Yr.no is a weather Service from the Norwegian Meteorological Institute and Encyclopaedia of nations (2012): africa, Nigeria. available at www.google.org.

United Nations (UN) (2010). Panel on Climate Change/Conference Report. The Way Forward.

Retrieved from www.hg.org/climatechange.htm retrieved (4/2/2014). 